\title{
CENOVÁ STATISTIKA STAVEBNICTVÍ
}

\author{
CONSTRUCTION PRICE STATISTICS
}

Ing. Nový Martin, CSc.

\begin{abstract}
ABSTRAKT
Vývoj cenové hladiny ve stavebnictví na úrovni vstupů (nákladů) i výstupů (cen) dlouhodobě sleduje Český statistický úřad. Publikované cenové indexy lze použít ve smlouvách o dílo uzavíraných mezi objednatelem a zhotovitelem staveb jako koeficient pro tvorbu pružných cen. Nejnovější výsledky roku 2015 ukazují, že s růstem objemu stavební výroby se deflační vývoj obrátil a v několika posledních čtvrtletích dochází $\mathrm{k}$ mírnému inflačnímu růstu cen.
\end{abstract}

Klíčová slova: Cenová statistika, cenový index, stavebnictví, pružná cena

\section{ABSTRACT}

Czech Statistical Office is constantly monitoring developments in the price level in the construction industry at the level of inputs (costs) and output (in prices). Published price indices can be used in contracts for work concluded between the client and the contractor building as a factor for the creation of flexible pricing. The latest results of 2015 show that the growth in production of construction output and a deflationary trend has reversed in the last few quarters there is a slight inflationary price increases.

Key words: Price statistics, price index, construction industry, flexible price

\section{VÝZNAM STAVEBNICTVÍ}

Téměř žádná lidská činností se neobejde bez použití výsledků stavební výroby, tj. staveb. Bydlení, doprava, kultura, vzdělávání, výroba, zdravotnictví, energetika - to všechno jsou oblasti individuálního nebo kolektivního využivání staveb. Stavební výroba má vazby na další odvětví hospodářství, která jí dodávají potřebné materiály, výrobky, energie, služby. Rostoucí požadavky na vstupy do stavebnictví tak vyvolávají růst produkce dodavatelů. Na realizované stavební investice navazuje v dalších letech růst výroby v ostatních odvětvích. Stavebnictví je tedy významnou součástí hospodársství každého státu a je proto nezbytné veškerým informacím spojeným s vývojem ve stavebnictví věnovat náležitou pozornost.

Výsledek stavební činnosti - stavební dílo - je vždy originální výrobek vysokého stupně komplexnosti, jehož časová a zdrojová náročností může dosahovat velkých hodnot. Cíl výstavbových projekti̊ se obvykle určuje ve třech rovinách - specifikační (provedení), časové (termíny) a nákladové (cena). Stavební dílo vzniká zabudováním stovek až tisíců různých materiálů, polotovarů a výrobků. Při jejich zpracovávání se uplatňují rozmanité technologie za účasti řady profesně odlišných pracovníků a používají se různá nářadí, stroje a zařízení. Prostředí stavby značně ovlivňuje pracnost a náklady na výrobu. Proto i shodné stavební konstrukce nebo práce se mohou lišit spotřebou zdrojů a tím i náklady a cenou.

Způsob a určení výše ceny za stavební práce je v tržním hospodářství věcí dohody zúčastněných stran, tj. investora a dodavatele. 
Obvyklým smluvním nástrojem ve stavebnictví je smlouva o dílo vymezená v Občanském zákoníku (zákon č. 89/2012 Sb.) (Nový občanský zákoník, 2014). Obě smluvní strany se musí dohodnout bud' př́mo na výši ceny, nebo na způsobu, jak bude tato cena stanovena. Vzhledem $\mathrm{k}$ tomu, že stavba může být značně rozsáhlá a nákladná, cena stavební části se většinou určuje skladebně z cen jednotlivých stavebních konstrukcí a prací. Ty jsou určeny slovním popisem, měřicí jednotkou, množstvím, cenou jednotkovou a cenou celkovou a jsou seřazeny v podrobném rozpočtu. Cena obsahuje veškeré náklady dodavatele (na materiál, mzdy, zákonné odvody, stroje, energie, řízení a provoz firmy) a jeho přiměřený zisk. Jednotkové ceny může určovat dodavatel na základě sledování vlastních nákladů nebo je může přejímat $\mathrm{z}$ databází sestavovaných specializovanými firmami anebo zjištovat na trhu. Do ceny funkční stavby je třeba ještě zahrnout náklady na inženýrskou a kompletační činnost, náklady na technologie, náklady spojené s umístěním stavby popř. další pořizovací náklady.

\section{CENOVÁ STATISTIKA}

Cenová statistika obecně zjištuje cenové údaje a z nich určuje cenovou hladinu formou cenových indexů. Cenová hladina je tvořena cenami mnoha druhů výrobků a služeb, jimiž se obchoduje. Cena jednoho druhu zboží může být různá časově (v různém období), ale i geograficky (na různých místech). Úkolem cenové statistiky je zjišt'ování stavu a vývoje cen a cenových hladin v členění podle oborů výroby resp. služeb (podle různých klasifikačních hledisek). V české statistické praxi se výsledky statistických zjištování cen organizovaných Českým statistickým úřadem, organizační složkou státu (dále jen ČSÚ) publikují ve formě cenových indexů v měsíční nebo čtvrtletní periodicitě. Některá šetření uveřejňují i vybrané cenové údaje (v Kč) jako doplňující informace.

Ceny se zjištují výběrovým způsobem u vybraných respondentů za určené reprezentanty. Reprezentant zastupuje skupinu zboží nebo služeb obdobného druhu se stejným nebo podobným cenovým vývojem. Má většinou významný podíl na obratu této skupiny a je zastoupen ve všech nebo většině geografických oblastí a časových obdobích.

Při výpočtu cenových indexů se použivá následující algoritmus. Pro každou dvojici vykázaných cen reprezentanta (od jednoho respondenta) se nejprve vypočte individuální index jako podíl ceny ve sledovaném období $\mathrm{k}$ ceně ve výchozím období. Ze všech individuálních indexů stejného reprezentanta (od různých respondentů) se dále vypočte prostý aritmetický průměr. Takto vypočtené indexy reprezentantů vybraných podle použité klasifikace, jejího stupně a položky se nakonec agregují do úhrnů (kumulací) i několika úrovní. V ČR se použivá pro výpočet cenového indexu $I$ výpočetní vzorec typu Laspeyres v modifikované podobě:

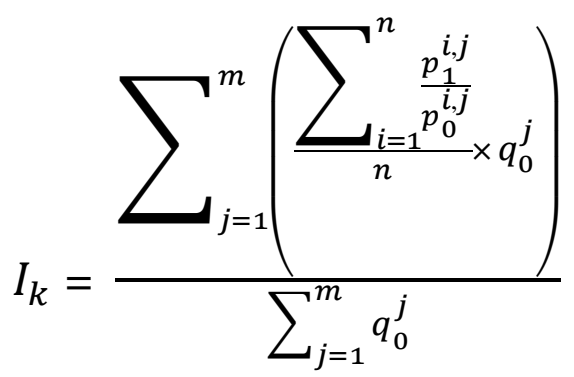

kde značí:

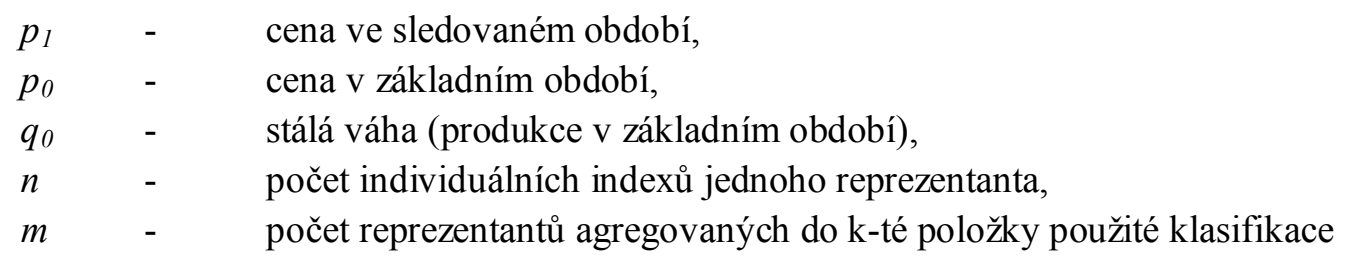


Vzorec (1) představuje vážený aritmetický průměr, kde indexy reprezentantů jsou váženy dílčími obraty, nebo je zastupujícími vahami ze základního období. Stálé váhy se určují z ukazatelů zjištěných př́íslušnou statistikou produkce.

\section{CENOVÁ STATISTIKA STAVEBNICTVÍ}

Obecně se cenové indexy dělí na indexy vstupů (nákladů) - tzv. input indexy a indexy výstupů - tzv. output indexy. Ve stavebnictví má výpočet indexů obou typů mnohaletou historii a v současnosti publikuje ČSÚ výsledky ve třech řadách:

- Indexy cen stavebních prací a stavebních děl (output),

- Indexy nákladů stavební výroby (input),

- Indexy cen materiálových vstupů stavební výroby (input).

Zjištování cen stavebních prací probíhá ve čtvrtletních intervalech, a proto je základním časovým obdobím čtvrtletí. Z výsledků čtvrtletního šetření označeného Ceny Stav 1-04, které je dlouhodobě součástí Programu statistických zjišstování (Vyhláška o Programu statistických zjišt’ování na rok 2016, 2015), se publikují i některé vybrané průměrné jednotkové ceny stavebních prací a hodnoty hodinových sazeb za práce prováděné specializovanými pracovníky. Indexy i ceny jsou počína za celou republiku.

Indexy cen stavebních prací a stavebních děl (objektů) se počítají na matematickém modelu, který obsahuje soupis vybraných stavebních a montážních prací (reprezentanty). Současná metodika používá k výpočtu cenových indexů vzorec (1).

Zjišt'ovaná cena stavební práce obsahuje kromě zabudovaného a spotřebovaného materiálu veškeré další náklady nutné k realizaci sledované činnosti (mzdové náklady, zákonné sociální a zdravotní pojištění, náklady na provoz stavebních strojů a mechanizmů, náklady dopravní mimo přesunu hmot, režijní náklady, mimořádné náklady vznikající v důsledku umístění a individuálního prostředí stavby, zisk), ale bez nákladů na zařízení staveniště a daně z přidané hodnoty. Sledovaným obdobím je prostřední měsíc čtvrtletí.

Vyšší agregace jsou představovány položkami určené klasifikace stavebních prací resp. stavebních děl. Indexní schémata se sestavují z položkových rozpočtů vybraných stavebních objektů a celkových objemů stavební produkce v ČR. Aktuální základní cenovou hladinou je rok 2005, váhy jsou aritmetickým průměrem produkční struktury stavebnictví za léta 2007 až 2010.

\subsection{Indexy cen stavebních prací a stavebních dèl}

Od roku 2004 jsou výsledky zpracování všech cenových statistik ve stavebnictví zveřejňovány ve čtvrtletní publikaci pod aktuálním názvem Indexy cen stavebních prací, indexy cen stavebních děl a indexy nákladů stavební výroby (Katalog produktů, 2015). Pro třídění výsledků stavební výroby stavebních objektů (děl) - se použivá Klasifikace stavebních děl CZ-CC. Tato klasifikace neobsahuje agregaci budov a inženýrských děl. Proto se uvádí jako zvláštní agregační položka stavební díla. Spolu s indexy za opravy a údržbu staveb a dalšími položkami je používá statistický Č́selník druhů staveb.

Od počátku roku 2012 jsou stavební konstrukce a práce tříděny podle systému číselníků TSKPstat, který vychází z klasického Třídníku stavebních konstrukcí a prací, jež lépe (a kontinuálně po desítky let) vyhovuje stavařské praxi. Indexy jsou uváděny za vybrané práce hlavní stavební výroby (HSV) a přidružené stavební výroby (PSV) členěné dále na skupiny stavebních dílů, stavební díly a řemesla. V tabulce na Obr. 1 jsou uvedeny cenové indexy vybraných položek TSKPstat v časové řadě za jednotlivá čtvrtletí od roku 2012. 
prúmér roku $2005=100$

\begin{tabular}{|c|c|c|c|c|c|c|c|c|c|c|c|c|c|c|c|c|}
\hline \multirow{3}{*}{$\begin{array}{l}\text { Kód } \\
\text { TSKP } \\
\text { stat }\end{array}$} & \multirow{3}{*}{ Název } & \multicolumn{4}{|c|}{2012} & \multicolumn{4}{|c|}{2013} & \multicolumn{4}{|c|}{2014} & \multicolumn{3}{|c|}{2015} \\
\hline & & \multicolumn{4}{|c|}{ čtvrtietí } & \multicolumn{4}{|c|}{ čtvrtietí } & \multicolumn{4}{|c|}{ čtvrtletí } & \multicolumn{3}{|c|}{ čtvrtietí } \\
\hline & & 1. & 2. & 3. & 4. & 1. & 2. & 3. & 4. & 1. & 2. & 3. & 4. & 1. & 2. & 3. \\
\hline & Konstrukce a práce HSV & 111,5 & 111,3 & 111,1 & 110,6 & 110,2 & 109,5 & 109,4 & 109,4 & 109,6 & 109,7 & 110,1 & 110,4 & 110,7 & 111,2 & 111, \\
\hline 27 & Základy & 107,1 & 106,9 & 107,0 & 106,2 & 105,8 & 105,1 & 105,0 & 104,7 & 105,0 & 105,2 & 105,6 & 106,0 & 106,2 & 106,6 & 107. \\
\hline 31 & Zdi pozemnich & 108,9 & 108,7 & 108,6 & 107,7 & 107,2 & 106,4 & 106,2 & 106,0 & 106,2 & 106,1 & 106,2 & 106,2 & 106,6 & 106,9 & 107. \\
\hline 41 & stropni konstr & 106,2 & 105,8 & 105,8 & 105,2 & 104,8 & 104,1 & 104,0 & 103,6 & 103,8 & 103,9 & 104,1 & 104,2 & 104,2 & 104,6 & 104 \\
\hline 722 & Zdravot & 121,9 & 122,1 & 122,2 & 122,5 & 122,4 & 122,6 & 122,7 & 123,2 & 123,6 & 124,2 & 124,6 & 125,0 & 125,7 & 126,9 & 127 \\
\hline 744 & Elehtrozarïzeni - rozvod vodičcu & 126,2 & 125,8 & 126,5 & 126.3 & 126,2 & 125.5 & 124,8 & 125,2 & 125.6 & 125,7 & 125,7 & 125,8 & 126,5 & 126,7 & 126 \\
\hline
\end{tabular}

\section{Obr. 1 Cenové indexy vybraných položek TSKPstat (zdroj dat ČSÚ)}

Cenová statistika stavebních prací rovněž publikuje průměrné ceny vybraných stavebních konstrukcí a prací za měřicí jednotku ve sledovaném čtvrtletí. Průměrná cena se počítá jako prostý aritmetický průměr ze všech vykázaných cen daného reprezentanta. Popis stavební práce vychází z popisu reprezentantů statistického šetření Ceny Stav 1-04 podle číselníků TSKPstat a klasifikace CZ-CPA doplněného o další upřesňující podmínky (Krajská správa ČSÚ v Hradci Králové, 2015). V roce 2015 je do systému zařazeno 137 reprezentantů umožňujících vykazovat ceny několika tisíců konkrétních stavebních prací. V tabulce na Obr. 2 jsou uvedeny průměrné ceny vybraných reprezentantů šetření Ceny Stav 1-04 opět v časové řadě za jednotlivá čtvrtletí od roku 2012.

\begin{tabular}{|c|c|c|c|c|c|c|c|c|c|c|c|c|c|c|c|c|c|}
\hline \multirow{3}{*}{$\begin{array}{c}\text { Kod. } \\
\text { podminky } \\
\text { a b }\end{array}$} & \multirow{3}{*}{ Näzer (zkràceno) } & \multirow{3}{*}{$\begin{array}{l}\text { Mêtic } \\
\text { jedn. }\end{array}$} & \multirow{2}{*}{\multicolumn{4}{|c|}{2012}} & \multirow{2}{*}{\multicolumn{4}{|c|}{$\frac{2013}{\text { cturtletit }}$}} & \multirow{2}{*}{\multicolumn{4}{|c|}{$\frac{2014}{\text { Etvitietif }}$}} & \multirow{2}{*}{\multicolumn{3}{|c|}{$\frac{2015}{\text { Cturtieti }}$}} \\
\hline & & & & & & & & & & & & & & & & & \\
\hline & & & 1. & 2 & 3. & 4. & 1. & 2 & 3. & 4 & 1. & 2 & 3. & 4. & 1. & 2 & 3. \\
\hline 008,22 & Hloubené yykopàky, nezapażené, strojné, tí. 3 & $\mathrm{~m}^{3}$ & 264,89 & 264.25 & 262,08 & 259,03 & 258,18 & 252,54 & 250,19 & 250,94 & 227,50 & 225,97 & 227,35 & 227,56 & 228,97 & 231,22 & 232,74 \\
\hline 026,12 & Zakladove pasy, beton C $1211 /$ az C 20/25 & $\mathrm{m}^{2}$ & 2500,68 & 2507,06 & 2512,19 & 2490,96 & 2470,65 & 2458,00 & 2460,67 & 2453,90 & 2432,02 & 2428,06 & 2429,58 & 2437,39 & 2439,68 & 2443.90 & 2448,78 \\
\hline 031,2 & Zdi pozemnich staveb nosné, zdêné, cihly pälené & $m^{2}$ & 3747,44 & 3720,95 & 3715,46 & 3686,40 & 3653,32 & 3624,76 & 3632,32 & 3633,49 & 3529,98 & 3547.29 & 3566.78 & 3577,29 & 3596,34 & 3603,39 & 3618,45 \\
\hline 050,11 & Stropy, prefa dilce, Zelezobeton, til do $150 \mathrm{~mm}$ & $m^{2}$ & 995,28 & 1002,06 & 1002,09 & 1001,65 & 997,87 & 996,43 & 995,76 & 1042.54 & 1072,50 & 1070,17 & 1072,17 & 1077,88 & 1080,22 & 1079,72 & 1084,05 \\
\hline 077,11 & Izolace proti vode, vodoromá, asfaltony pás & $\mathrm{m}^{2}$ & 214,87 & 213,80 & 213,75 & 213.99 & 214,18 & 213,01 & 210,95 & 208.39 & 190,07 & 190,38 & 190,83 & 192.68 & 194,30 & 194.38 & 196,35 \\
\hline 082,31 & Vodovod unitini, plast, prùmer do $25 \mathrm{~mm}$ & m & 192,10 & 193.49 & 194.07 & 195,88 & 198,68 & 198.35 & 199,18 & 199,46 & 216.36 & 217,41 & 219,84 & 221.27 & 221,08 & 222,59 & 223.28 \\
\hline 093.21 & Roxad vodicú, méd, jindnotilow do $4 \mathrm{~mm}^{2}$ & $\mathrm{~m}$ & 32.61 & 32.50 & 31.85 & 31.91 & 31.83 & 31.95 & 31,54 & |31.93 & 38.09 & 43.73 & 44,10 & 44.36 & 43.16 & 43.65 & 44,13 \\
\hline
\end{tabular}

Obr. 2 Průměrné ceny vybraných reprezentantů stavebních prací (zdroj dat ČSÚ)

\subsection{Indexy nákladů stavební výroby}

Další publikovanými výstupy cenové statistiky jsou indexy nákladů stavební výroby ve tř́́dění podle položek Číselníku druhů staveb. Ve výpočtu tohoto typu indexů jsou zohledněny veškeré náklady stavebních firem, které jim při realizaci stavebních prací vznikají a jež obsahuje běžně použivaný kalkulační vzorec ceny stavební práce. Zisk se nezapočítává, protože není pro stavební firmu nákladem. Tento výpočet nemá vlastní výkaznictví, použivají se při něm sekundární datové zdroje již jinde zjištěné nebo vypočítané ukazatele. Na Obr. 3 je v grafu zobrazen vývoj indexů nákladů stavební výroby ve srovnání s indexy cen stavebních děl. 


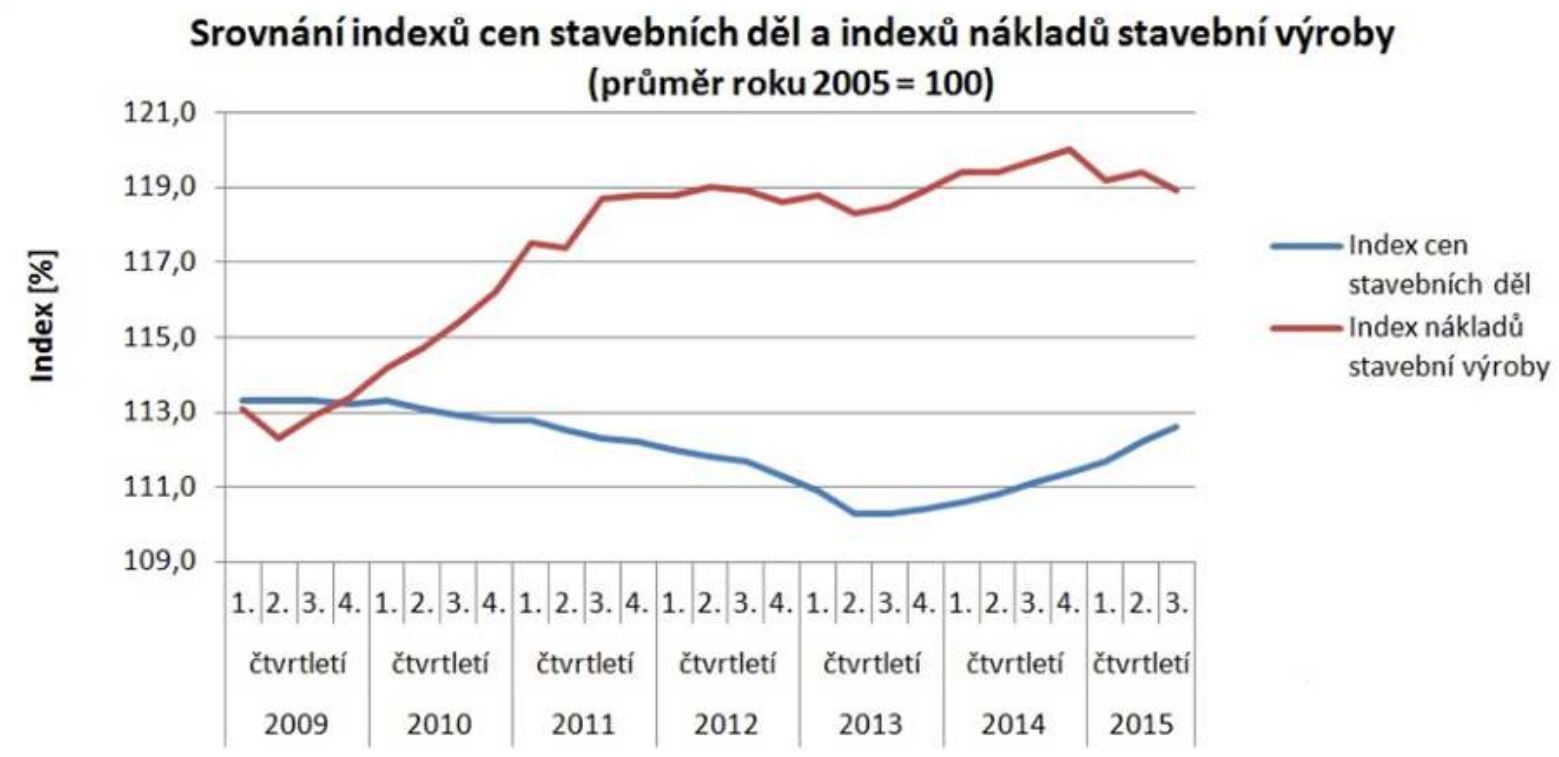

Obr. 3 Graf indexů cen stavebních děl a nákladů stavební výroby (zdroj dat ČSÚ)

\subsection{Indexy cen materiálových vstupů stavební výroby}

Největší náklad ve stavebnictví představují stavební materiály, polotovary a výrobky zabudovávané do staveb. Proto se samostatně počítají cenové indexy materiálů a výrobků spotřebovaných ve stavebnictví, použivaných stavebních strojů a spotřebovávaných pohonných hmot a energií. Obr. 4 obsahuje graf s vývojem cenových indexů materiálových vstupů ve struktuře Č́selníku druhů staveb.

Indexy cen materiálových vstupů stavební výroby podle číselníku druhů staveb (průměr roku $2005=100$ )

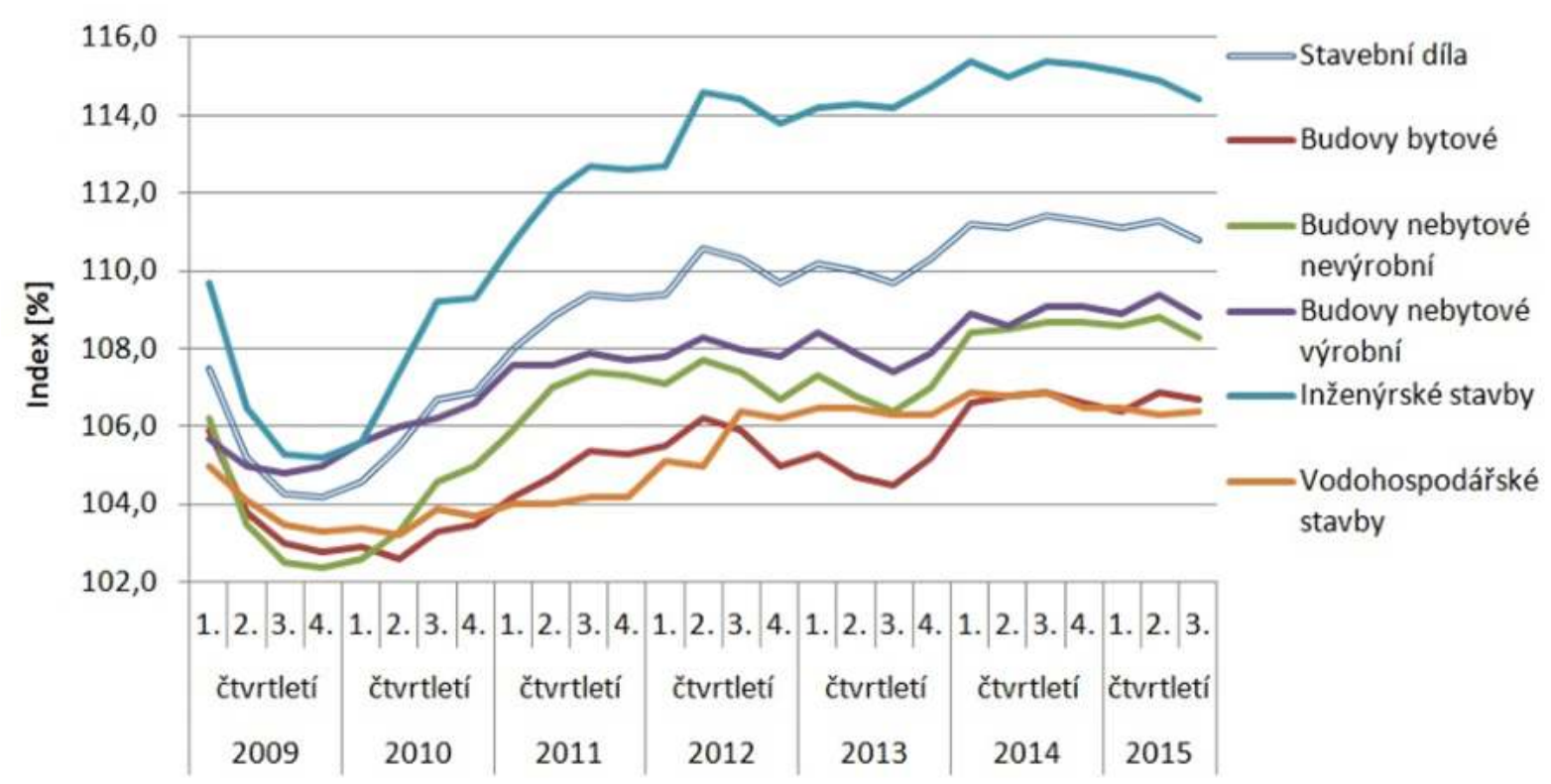

Obr. 4 Graf indexů materiálových vstupů stavební výroby (zdroj dat ČSÚ) 


\section{POUŽITÍ VÝSLEDKU゚ CENOVÉ STATISTIKY}

Ve stavebnictví se indexy cen stavebních prací použivají ve smlouvách o dílo. Cena stavebního objektu se obvykle určuje jednorázově v prováděcím rozpočtu. Mezi časem sestavení rozpočtu a časem realizace stavby nebo práce uplyne řada měsíců, někdy i let. $\mathrm{V}$ tomto období dochází $\mathrm{k}$ pohybu cenové hladiny. Cenový index lze pak použít jako koeficient upravující cenu za postupně prováděné a fakturované práce (zatříděné podle TSKPstat) oproti cenám rozpočtovaným. Lze použít rovněž index přiřazený celému stavebnímu objektu podle CZ-CC. Ve smlouvě musí být jasně definován druh použitého indexu, frekvence jeho aktualizace popř. i způsob výpočtu časového koeficientu. Indexy lze použit i pro jednorázovou aktualizaci dříve sestavených rozpočtů objektů zatříděných podle CZ-CC.

Indexy nákladů stavební výroby a indexy cen materiálových vstupů lze využívat v managementu stavebních firem jako průměrnou srovnávací hladinu s vlastními ekonomickými ukazateli.

Cenové indexy se rovněž použivají pro stanovení koeficientu změny cen staveb v metodice podle Vyhlášky 441/2013 Sb. k provedení zákona o oceňování majetku (oceňovací vyhláška) v platném znění (Vyhláška k provedení zákona o oceňování majetku, 2013). Ceny publikované v oceňovacích vyhláškách jsou vztaženy k cenové úrovni roku 1994 a násobením základní ceny koeficientem změny cen staveb se přepočtou do aktuální cenové úrovně.

Cenové indexy ve stavebnictví mohou používat soukromí investoři při sledování vývoje cenové hladiny staveb a adekvátnosti nabídkových cen. Průměrné ceny stavebních prací je možné použivat jako jeden ze standardů při vyhodnocování soutěžních nabídek.

Cenové indexy se dále používají ve statistice produkce jako tzv. deflátory pro přepočet objemů produkce $\mathrm{z}$ cen běžných do cen stálých. Velikost produkce lze pak v čase srovnávat s vyloučením vlivu inflace. Vybrané hodnoty cenových indexů stavebnictví se použivají v dalších statistických výpočtech a jsou rovněž předávány statistickému úřadu Evropské unie - Eurostatu.

Cenové indexy jsou ve stavebnictví důležitým nástrojem na jednoduché a výstižné aktualizace cenových údajů. Nejnovější publikace s tabulkami indexů i jejich starší vydání od roku 2010 jsou k dispozici na internetových stránkách ČSÚ (Katalog produktů, 2015). Při nevhodném či přímo chybném použivání cenových indexů však mohou vzniknout značné finanční ztráty. Je třeba mít stále na mysli, že cenový index je vždy poměrným ukazatelem srovnávajícím aktuální cenovou hladinu s hladinou výchozí a to vždy za průměrných realizačních podmínek na celém území republiky. Je proto nezbytně nutné mít pro správné použití cenových indexů znalosti z oblasti statistiky cen nebo vyhledat odbornou pomoc. 


\section{Použitá literatura}

[1] Katalog produktů: Český statistický úřad. 2015. Indexy cen stavebních PRACí, indexy cen stavebních děl a indexy nákladů stavební výroby [online]. Praha: ČSÚ, 2015-11-24 [cit. 2015-11-25].

[2] Krajská správa ČSÚ v Hradci Králové: Český statistický úruad. 2015. Ceny stavebních prací [online]. Hradec Králové: ČSÚ, 2015-04-14 [cit. 2015-11-25].

[3] Nový občanský zákoník: zákon č. 89/2012 Sb. ze dne 3. února 2012. 2014. 1. Praha: Ústav práva a právní vědy, 320 s. Právo a management. ISBN 9788087974018.

[4] Vyhláška k provedení zákona o oceňování majetku. 2013. In: Sbírka zákonů Česká republika. Praha: Tiskárna Ministerstva vnitra, p.o., ročník 2013, 441/2013 Sb.

[5] Vyhláška o Programu statistických zjišstování na rok 2016: 302/2015 Sb. 2015. In: Sbírka zákonů Česká republika. Praha: Tiskárna Ministerstva vnitra, p. o., ročník 2015, částka 128. 